\title{
The Analysis Of Factors Affecting The High Level Of Pharmacy Turnover Of Pharmaceutical Installations In "Karangploso" Hospital Malang Regency
}

\begin{abstract}
Sony Wiraganda

Pharmacy personnel include pharmacists and pharmacy technicians who are important HR in hospitals. The assessment was carried out Magister of Health Study Program of based on an increase in the percentage of entry and exit or turnover Institut Ilmu Kesehatan STRADA Indonesia

Email: sonywiraganda@gmail.com

Received : October 12, 2019

Accepted : February 13, 2020

of pharmacy staff at the "X" Hospital in 2017 by $33 \%$ ( 9 employees 3 who left), in 2018 by 55\% (5 of 9 employees) and in 2019 by $45.4 \%$ (5 out of 11 employees leaving), "X" Hospital is a type C hospital located in Karangploso that serves general and specialist cases. the high turnover has an impact on organizations and individuals in organizations in the financial sector resulting in increased recruitment and training costs in the non-financial sector causing damage to social structure in the organization and a decrease in service quality, the purpose of this study is to determine the factors and causes of high employee turnover rates in pharmaceutical research plants in do qualitatively with approaches to three primary informants and 13 secondary informants. Data collection is done by interviews, observations and studies of research documents conducted in the outpatient pharmacy installation room (IFRJ) inpatient pharmaceutical installation (IFRI) and the Drug Warehouse Unit (UGO). It was found that what caused the turnover were: high workload, lack of energy, non-transparent distribution of incentives, lack of appreciation, dualism of leadership, and low organizational commitment. while the most influential factor being the main cause of turnover is the lack of appreciation and high workload. Advice hospital should make technological application breakthroughs to reduce workloads
\end{abstract}

Published : May 12, 2020
Keywords: Pharmaceutical Personnel, Turnover, Workload

\section{(ㅇ) (1) ( )}

This is an open-acces article distributed under the terms of the Creative Commons Attribution-ShareAlike 4.0 International License. 


\section{INTRODUCTION}

Pharmacy staff is an important HR in a hospital. These workers are divided into pharmacists and pharmaceutical technical workers. In 'Karangploso' Hospital, pharmacy turnover increased by 2017 by 33\% (9 employees 3 left), in 2018 by 55\% (5 of 9 employees) and in 2019 by 45.4\% (5 out of 11 employees left), Turnover intention is one's desire to leave the company / organization Abelson (1987). Turnover intention can affect hospital services. Poor new pharmacy service can reduce hospital performance which can be seen from the level of hospital occupancy efficiency, decreased hospital turnover and decreased patient satisfaction.

Several factors affect turnover according to theory (Wang et al., 2012): Job Satisfaction, Organizational Commitment, Leadership, Job Stress, Work Motivation, Awards. Based on Mobley (2011: 42) Turnover has an impact on organizations and individuals, on organizations turnover has an impact on the financial sector, namely an increase in training budgets and recruitment of new employees on nonfinance, namely a decrease in service quality, an impact on individuals, namely the loss of a social system that has been formed.

This study aims to prove and find out the problems that occur in the pharmacy installation room and explore the main causes of pharmacy staff turnover at the ' $\mathrm{X}$ ' Hospital and explore the main causes of problems that are potential causes of turnover.

\section{METHODS}

This research is a qualitative research with an instrumental case study approach. The problem of turnover intention is examined through pharmacy staff when having turnover intention and after turnover. Data collection techniques used interviews with 3 primary informants and 13 secondary informants), observations on the activities of pharmaceutical officials, and documents found at the time of the study. Data and analysis is done by data reduction (coding, making analysis notes and provisional reports), validity so that the data can be trusted using the appropriate triangulation method (Cresswell, 1998).

\section{RESULTS}

The study was conducted at a type $\mathrm{C}$ hospital in Karangploso district, Malang. Hereinafter referred to as the "X" hospital with 157 beds. The research was carried out in the Outpatient Pharmacy Installation (IFRJ), Inpatient Pharmacy Installation (IFRI) and Drug Warehouse Unit (UGO) for the selection of these three places because it is the work area of the pharmaceutical officer.

\section{Descriptive Public Data}

\begin{tabular}{|c|c|c|c|c|c|c|}
\hline $\begin{array}{c}\text { Initial } \\
\text { Informant } \\
\text { FA }\end{array}$ & Gender & $\begin{array}{c}\text { Age } \\
\text { (year) } \\
\text { Male }\end{array}$ & $\begin{array}{c}\text { Level of } \\
\text { education } \\
\text { SI }\end{array}$ & $\begin{array}{c}\text { Position } \\
\text { Farmasi }+ \\
\text { profesi apoteker }\end{array}$ & $\begin{array}{c}\text { Length of } \\
\text { work } \\
\text { (year) } \\
8 \text { bln } \\
\text { outpatient } \\
\text { pharmacy }\end{array}$ & Information \\
\hline SD & Male & 27 & D3 Farmasi & $\begin{array}{c}\text { Inpatient } \\
\text { pharmacy }\end{array}$ & 1 & $\begin{array}{c}\text { Informan } \\
\text { Primary } \\
\text { Informant }\end{array}$ \\
\hline FR & Female & 30 & D3 farmasi & $\begin{array}{c}\text { Pharmaceutical } \\
\text { warehouse }\end{array}$ & 1 & $\begin{array}{c}\text { Informan } \\
\text { Primary } \\
\text { Informant }\end{array}$ \\
\hline DR & Female & 27 & D3 & $\begin{array}{c}\text { Informan } \\
\text { pharmacy }\end{array}$ & $\begin{array}{c}\text { Secondary } \\
\text { Informant }\end{array}$ \\
\hline
\end{tabular}


The Analysis Of Factors Affecting The High Level Of.....

\begin{tabular}{|c|c|c|c|c|c|c|}
\hline TM & Male & 27 & $\begin{array}{c}\text { D3 } \\
\text { farmasi }\end{array}$ & $\begin{array}{l}\text { Inpatient } \\
\text { pharmacy }\end{array}$ & 1 & $\begin{array}{c}\text { Informan } \\
\text { Secondary } \\
\text { Informant }\end{array}$ \\
\hline $\mathbf{A N}$ & Female & 27 & $\begin{array}{c}\text { D3 } \\
\text { farmasi }\end{array}$ & $\begin{array}{l}\text { outpatient } \\
\text { pharmacy }\end{array}$ & 1 & $\begin{array}{l}\text { Secondary } \\
\text { Informant } \\
\text { Secondary } \\
\text { Informant }\end{array}$ \\
\hline MT & Female & 29 & $\begin{array}{c}\mathrm{D} 3 \\
\text { farmasi }\end{array}$ & $\begin{array}{l}\text { outpatient } \\
\text { pharmacy }\end{array}$ & 4 & $\begin{array}{c}\text { Informan } \\
\text { Secondary } \\
\text { Informant }\end{array}$ \\
\hline RL & Female & 20 & $\begin{array}{c}\mathrm{D} 3 \\
\text { farmasi }\end{array}$ & $\begin{array}{c}\text { Pharmacy } \\
\text { Officer } \\
\text { IFRI }\end{array}$ & 1 & $\begin{array}{c}\text { Informan } \\
\text { Secondary } \\
\text { Informant }\end{array}$ \\
\hline $\mathbf{H}$ & Male & 27 & $\begin{array}{l}\text { S1 farmasi } \\
+ \text { profesi }\end{array}$ & $\begin{array}{l}\text { Inpatient } \\
\text { pharmacy }\end{array}$ & 1 & $\begin{array}{c}\text { Informan } \\
\text { Secondary } \\
\text { Informant }\end{array}$ \\
\hline $\mathbf{A L}$ & Female & 27 & D3 farmasi & $\begin{array}{l}\text { Inpatient } \\
\text { pharmacy }\end{array}$ & 3 & $\begin{array}{c}\text { Informan } \\
\text { Secondary } \\
\text { Informant }\end{array}$ \\
\hline FI & Female & 33 & S1 Psikologi & HRD & 3 & $\begin{array}{c}\text { Informan } \\
\text { Secondary } \\
\text { Informant }\end{array}$ \\
\hline $\mathbf{W}$ & Female & 30 & $\begin{array}{c}\text { D3 } \\
\text { farmasi }\end{array}$ & $\begin{array}{c}\text { Pharmaceutical } \\
\text { warehouse }\end{array}$ & 1 & $\begin{array}{c}\text { Informan } \\
\text { Secondary } \\
\text { Informant }\end{array}$ \\
\hline $\mathbf{Y U}$ & Female & 44 & $\begin{array}{c}\text { S1 } \\
\text { Kedokteran }\end{array}$ & $\begin{array}{l}\text { Medical } \\
\text { services } \\
\text { manager }\end{array}$ & 1 & $\begin{array}{c}\text { Informan } \\
\text { Secondary } \\
\text { Informant }\end{array}$ \\
\hline MA & Male & 46 & $\begin{array}{c}\text { S1 } \\
\text { Kedokteran }\end{array}$ & Research & 4 & $\begin{array}{c}\text { Informan } \\
\text { Secondary } \\
\text { Informant }\end{array}$ \\
\hline
\end{tabular}

\section{Results data, based on the informed}

A. Job Description of Pharmacy Officers in IFRJ in RSX and the Problems

IFRI, IFRI and UGO are service units located in RSX. IFRJ is a hospital outpatient pharmacy unit that provides services to the needs of outpatient medicine based on research results. There is one finding that the act of recording narcotic drugs was carried out by pharmacist asiten officers who should be carried out by the pharmacist in charge for further reporting of these narcotic drugs not in accordance with the SPO (Standard Operating Procedure) and the pharmacist agreement at IFRJ which states that these reporting and recording actions should be carried out by pharmacists not pharmacist assistants

W/02.12.19/09.00/IFRJ/AN

“jarang apoteker nya mau nulis pak,soalnya kadang apotekernya Cuma pagi kalau butuh obat narkotika sore gimana he he he..."

\section{W/09.12.19/08.00/IFRJ/DR}

"Kalau menulis gitu nunggu apotekernya kadang suka lupa sama obat yang udah di keluarkan,takutanya malah gak kecatet,kadang beberapa hari baru di rekap "

Based on the results of the study some of the problems found by researchers at IFRJ RSX are the lack of pharmacy officers according to interviews with the code (W / 02.12.19 / 08.00 / IFRJ / H), 
high workload (W / 02.12.19 / 08.00 / IFRJ / H), lack of facilities and infrastructure (W / 02.12.19 / 09.00 / IFRJ / SR), inconsistencies in calculating the amount of incentives with workloads, work that is not in accordance with the competencies W / 02.12.19 / 09.00 / IFRJ / AN, various procedures insurance patient administration services (drugs covered by each insurance along with how to enter different applications) (W / 02.12.19 / 09.00 / IFRJ / SR) and leadership dualism

\section{B. Job Description of Pharmacy Officers at IFRI in RSX and the Problems}

Some problems found by the researchers There were a number of cases that should have been decided by the director. But the director was considered lacking firmly because it still cannot provide its own decisions regarding matters related to HR. The uncertainty is because the director has not yet been given full control by the owner, so there are several HR policies that still cannot be fully implemented, especially regarding the number of personnel that must be placed at IFRI.

W/18.01.20/19.00/IFRI/RL

"Sebenarnya dr.A sudah tau apa permasalahan kita disini, tapi terkadang untuk prakteknya masih susah dilakukan. Karena ya itu kurang tegas. Maksudnya kurang tegas itu ya ada beberapa kebijakan SDM yang masih mengikuti apa kata owner "

Another problem found by researchers when conducting observations is ineffectiveness when delivering drug distribution to inpatients. The order can change depending on the time of arrival of specialist doctors to conduct inpatient visits. Because additional prescriptions cannot be predicted so that additional prescriptions appear at unexpected times. In summary, the pharmacist's problems encountered at IFRI are: lack of appropriate pharmacy staff interview with code (W / 11.01.20 / 14.00 / IFRI / TM), high workload according to code interview (W / 02.01.20 / 09.00 / IFRI / TM), lack of facilities and infrastructure (W / 02.01.20 / 09.00 / IFRI / TM), inconsistencies in the amount of incentives with workload (W / 11.01.20 / 14.00 / IFRI / TM), one of the specialist doctors who are not liked (W / 11.12.19 / 14.00 / IFRI / H), and dualism leadership (W / 02.01.20 / 19.00 / IFRI / TM)

\section{Job Description of Pharmacy Officers at UGO RSX and Their Problems}

UGO personnel consisting of only two pharmaceutical officers have difficulty if one of the officers is sick, so when many drug orders come and have to enter the next shift the officer is often overwhelmed

W/14.12.2019/12.00/UGO/W

"Yah karena petugas Cuma dua kadang kalau pas saya sakit atau ijin tidak bisa gantian,sedangkan obat kan kadang datang di saaat tertentu"

In summary, the problems encountered by UGO pharmacy officers while working in RSX are: the lack of pharmacy staff according to the interview W / 14.12.2019 / 12.00 / UGO / W, the complicated flow of cyto new drug ordering (W / 14.12.2019 / 12.00 / UGO / FR), high workload, inconsistency between the amount of incentive and workload (W / 14.12.2019 / 12.00 / UGO / W) and, the existence of leadership dualism (W / 14.12.2019 / 12.00 / UGO / FR)

Table 4.1.4 Problems Arising During Pharmacy Workers Work

\begin{tabular}{|c|l|}
\hline \multicolumn{2}{|c|}{ Farmasi outpatient } \\
\hline$\circ \bullet$ & lack of officers \\
\hline$\circ \bullet$ & high workload \\
\hline$\circ \bullet$ & lack of facilities and infrastructure \\
\hline
\end{tabular}




\begin{tabular}{|c|l|}
\hline$\circ$ & mismatch of incentive magnitude \\
\hline$\circ \bullet$ & work that is not in accordance with competence \\
\hline$\circ \bullet$ & a variety of insurance services \\
\hline$\circ \bullet$ & leadership dualism \\
\hline \multicolumn{2}{|l}{} \\
\hline$\circ \bullet$ & Farmasi inpatient \\
\hline$\circ \bullet$ & lack of officers \\
\hline$\circ \bullet$ & lack of facilities and infrastructure \\
\hline$\circ \bullet$ & inconsistencies in the amount of incentives \\
\hline$\circ \bullet$ & there are doctors who are not liked \\
\hline$\circ \bullet$ & leadership dualism \\
\hline
\end{tabular}

\begin{tabular}{|c|l|}
\hline \multicolumn{2}{|c|}{ Drug Warehouse } \\
\hline$\circ \bullet$ & lack of officers \\
\hline$\circ \bullet$ & the complexity of drug ordering flow \\
\hline$\circ \bullet$ & high workload \\
\hline$\circ \bullet$ & inconsistencies in the amount of incentives \\
\hline$\circ \bullet$ & leadership dualism \\
\hline
\end{tabular}

D. Problems that have the Most Potential to Trigger Turnover Intention of Pharmacy Officers at RSX

Of the problems that have the potential to trigger turnover intentions that have been identified, there are problems that have the most potential to trigger turnover intentions. In the last interview conducted by researchers to elementary school (W / 22.12.19 / 11.00 / IFRI / SD), it was found that there are two things that most make him have a great desire to get out, namely high workload and lack of RSX appreciation towards him

Similar to SD, FA and FR stated that the problems that most made him have a strong desire to leave were high workloads and lack of appreciation (W / 11.12.19 / 14.00 / RD / FI). The workload is the first answer given by the FA when researchers ask about their reasons for leaving. This was reinforced from the results of interviews with secondary informants (TM) which stated that the first reason the FA quit was a feeling of fatigue due to high workload (W / 11.12.19.00 / HRD / FA).

T: "Apa yang melandasi mas FA untuk keluar...?"

J: "Ya capek pak, beban kerjanya itu...."

(W/11.12.19/14.00/RD/FA)

FI : "SD mengundurkan diri. Alasan yang pertama karena sangat kecapean,"

(W/19.12.19/14.00/HRD/FI)

The second problem is the lack of appreciation, which is an incentive that AI feels is not fair. Inequality meant by AI is the inconsistency of the amount of incentives compared to workload. Based on the analysis, it is known that the problem that has the most potential to trigger turnover intention of pharmacists in RSX is the lack of appreciation. Besides the existence of leadership dualism, HR policies are inconsistent and affect the whole set of issues of turnover intention of 
pharmacists in RSX, so leadership dualism is a fundamental problem in the turnover intention of RSX pharmacy officers.

\section{DISCUSSION}

In general, IFRJ Pharmacy Officers carry out their work in accordance with competency standards made by the Indonesian Pharmacy Experts Association. During the observation of IFRJ pharmacy work carried out by Pharmacy Officers including: manufacturing including quality control of pharmaceutical preparations, security, procurement (checking with a stock system hospitalization), storage and distribution or distribution of drugs, drug management, prescription drug services, drug information services, and drug development. This is in accordance with the Work Guidelines for Pharmaceutical Officers in Hospitals issued by the Indonesian Ministry of Health in 1963

During the IFRJ Pharmacy Officers do their work, there are a number of things that become a problem, including: lack of pharmaceutical staff, high workload, lack of facilities and infrastructure, incompatible calculation of the amount of incentives with workload, work that is not in accordance with competence, various procedures insurance patient administration services (the drugs covered by each insurance and their entry into different applications) and leadership dualism. These problems can potentially cause turnover intention in the Pharmacy Officers at RSX.

At IFRI, several problems were found related to the work of Pharmacy Officers. From these problems, there are seven problems that are the same as those found in IFRJ, namely; insufficient number of Pharmacy Officer in the Indonesian Embassy, high workload, lack of supporting facilities and facilities, calculation of the amount of unfair incentives, and leadership dualism. Whereas three different problems, namely: one of the specialist doctors who are not liked, and the ineffectiveness of drug delivery hours when there are additional prescriptions on the doctor's visit hours that are uncertain.

The existence of some of the same problems as at IFRJ reflects that the system prevailing at the hospital not only causes problems for Pharmacy Officers at IFRJ, but also at Pharmacy Officers at IFRI. Another thing to note is that Pharmacy Officers at IFRI have more problems than Pharmacy Officers at IFRJ, so that their vulnerability to turnoverintention can be considered greater (Kreitner and Kinicki, 2004). Besides that there is one of the first specific problems at IFRI is the existence of one of the specialist doctors that pharmacists dislike. The Pharmacy Officer's relationship in his work is not only with his colleagues but also with specialist doctors as work partners. Pharmacy Officers dislike the specialist doctor because the doctor is easily upset when there is a drug that is not ready according to the prescription expected by the doctor. This condition causes the Pharmacy Officer feels uncomfortable in working with the doctor. Discomfort that arises can affect the satisfaction of Pharmacy Officers in their work so as to cause turnover intention (Wang et al., 2012).

The problem that arises in the UGO room is the number of Human Resources (HR) of pharmaceutical officers in this room is only two, and there are no plans to add from the HR this is because according to the hospital manager and owner this room is not too heavy workload, but that is the opinion personally, according to pharmaceutical officials working in the heavy drug warehouse unit room. The low level of organizational commitment is directly related to their low job satisfaction (Suhanto, 2009).

As a consequence the Pharmacy Workload is based only on estimates. This is a problem when the number of patients who are one component of the workload has increased significantly. In addition to an increase in the number of patients an increase in the form of more complete surgical services makes drugs that sometimes are not available in stock more often and makes officers overwhelmed looking for distributors in addition to the difficulty of the flow of requests in hospitals "X".

This causes a heavy workload that will cause stress at work (Greenberg and Baron, 1997). Robins (2003) in Suhanto (2009) states that workload and work stress have a direct relationship to job satisfaction.

The amount of incentives in UGO that is not clear and transparent makes pharmaceutical employees feel dissatisfied with the intensive scale received. The unfair calculation of incentives can affect the job satisfaction of UGO Pharmacy Officers (Sulaiman, 2011). that all get

In general, work problems at UGO are related to high workloads, unfair incentives, work stress 
influences organizational commitment and job satisfaction. Both of these (organizational commitment and job satisfaction) can lead to turnover intentions in Pharmacy Officers (Lewis, 2008; Perez, 2008; Wang et al., 2012).

\section{A. Problems That Potentially Cause Turnover IntentionPharmacy Officer at RSX}

From interviews with informants at IFRJ, UGO and IFRI, several problems have the potential to cause turnover intention at RSX, namely high workloads, unfair incentives, feelings of lack of respect, leadership dualism, boredom towards work and other job offers.

High workload, unfair incentives, and feelings of underappreciation are all factors that influence the pharmacist's job satisfaction. High workload, unfair incentives including extrinsic factors of job satisfaction, while feelings of underappreciation are motivational factors that affect job satisfaction. Herzberg's theory states that extrinsic factors are factors that are around the implementation of work. The extrinsic factor is not enough to make employees fully satisfied. These factors only ensure that employees do not feel dissatisfied or at the zero point of motivation, while rewards which are motivational factors can encourage a person to feel job satisfaction (Yulida and Harlyanti, 2009). Another problem is the dualism of leadership in RSX

Both sources of these problems, job satisfaction and organizational commitment have the potential to influence the turnover intention of the Pharmacy Officers in the RSX as found in several previous studies by Supriati (2013). Other research by Vandenberg and Nelson (1990) states that organizational commitment and job satisfaction are predictors of turnover intention. In addition, Igbaria and Greenhaus (1992) suggest that job satisfaction and organizational commitment have a great influence on turnover intention (Suhanto, 2009).

\section{B. Problems with the Most Potential to Trigger Turnover IntentionPharmacy Officer at RSX}

Based on data synthesis, the problem that has the most potential to trigger their turnover intention is the lack of appreciation. The award is an appreciation given from the company / organization to its employees who make achievements in financial and non financial form so that the employee is motivated to achieve the goals of the company (Tampubolon, 2013)

Rewards can be in the form of financial (money) or non-financial. One form of appreciation in the form of money is an incentive. According to Panggabean (2002) incentives are direct rewards beyond salaries given to employees because their performance exceeds the standards given (Tampubolon, 2013)

It can be seen that the main factors causing turnover intention come from job satisfaction and low organizational commitment. Job satisfaction and low organizational commitment stem from a lack of appreciation. These results are consistent with research which says that lack of appreciation leads to dissatisfaction with work and a lack of commitment to hospitals which ultimately results in turnover intention (Andini, 2006; Kreitner and Kinicki, 2004). This pattern description is similar to the picture of the turnover pattern proposed by March and Simon which states that employee turnover intention is influenced by job satisfaction (Perez, 2008).

\section{CONCLUSION}

There are problems that arise due to the work situation of pharmaceutical officers in IFRJ, IFRI and UGO. Of these problems, seven of them are the same problem namely; lack of pharmacy officers, high workload, lack of facilities \& infrastructure, inconsistencies in calculating incentives with workloads, pharmacy staff work that is not in accordance with competence, leadership dualism and various procedures for patient insurance service flow. Besides that, there are specific problems found in IFRI, namely: one of the specialist doctors that is not liked. Specific problems found in UGO are: only two officers.

Based on work problems found in IFRJ, IFRI and UGO as well as interviews with informants, there are problems that have the potential to cause turnover intentions in pharmacy staff at the "X" Hospital: high workload, unfair incentives, dualism of leadership, boredom towards work and other job offers.

The problem that has the most potential to trigger turnover intention in pharmacy officers at the " $\mathrm{X}$ " Hospital is the lack of appreciation that affects turnoverintention through job satisfaction and organizational commitment. Besides that, dualism of leadership is a basic problem that causes a series of turnover intention problems of pharmaceutical officers in " $\mathrm{X}$ " hospitals. 


\section{REFERENCE}

Creswell, JW 1998, Qualitative Inquery and Research Design Choosing Among FiveTradition, SAGE Publication, United Stated of America.

Creswell, JW 2011, Qualitative Research, Pearson, New York

Djaelani, AR 2013, 'Tehnik Pengumpulan Data pada Penelitian Kualitatif', Majalah IlmiahPawiyatan, vol. 20, pp. 82-92.

Hariyati, M 2017, Pengaruh Beban Kerja Terhadap Kelelahan Kerja Pada Pekerja Linting Maunual di PT. Djitoe Indonesia Tobacco Surakarta, UniversitasSebelasMaret

Nanditya, IF 2014, 'kajian turnover permasalahan dan penyebab ; Jurnal UB 2014 Review of employee turnover influence Yanjuan Zhang (china) 2016

Ribhan 2011, 'Internal marketing; dampak job satisfaction, organizational comittment pada customers satisfaction ', Fokus Ekonomi (FE),, vol. 10, pp. 81-99.

Risanti, KA 2012, Analisis Pengaruh Motivasi Kerja Teradap Produktivitas Kerja KaryawanPada Perusahaan Daerah Air Minum Kota Makassar, Universitas Hasanuddin.

Siagian, S 2003, Teori dan Praktek Kepemimpinan, PT Rineka Cipta, Jakarta.

Sumarni, M 2011, 'Pengaruh employee retention terhadap turnover intention dan kinerja karyawan', Akmenika UPY, vol. 8, pp. 20 - 47.

Sunindhia, YW \& Widiyanti, N 1998, Penerapan manajemen dan kepemimpinan dalampembangunan, Bina Aksara, Jakarta.

Supriati 2013, 'Pengaruh Komitmen Organisasi terhadp Turnover Intention Dosen pada Politeknik Bengkalis', Inovbiz, vol. 1, pp. 57-73.

Tampubolon, BHP 2013, Penghargaan dan Sanksi (Studi Pada Pelaksana PT. PerkebunanNusantara IV Unit Kebun Mayang), Universitas Diponegoro.

Wang, L, Tao, H, Ellenbecker, CH \& Liu, X 2012, 'Job satisfaction, occupational commitment and intent to stay among Chinese nurses: a cross-sectional questionnaire survey', Journal of Advanced Nursing, vol. 68, no. 3, pp. 539-49. a9h database.Article.

Widyasari,Ni Made 2017,Pengaruh Ketidakamanan Kerja dan Kompensasi Terhadap Kepuasan Kerja dan Turn Over Intention Karyawan di Besakih Beach Hotel Denpasar,Universitas Udayana

Yulida \& Harlyanti, SW 2009, 'Faktor- faktor yang mempengaruhi kepuasan kerja pegawai pada pegawai pengawas dinas luar asuransi jiwa bersama bumiputra 1912 cabang setiabudi Medan', Jurnal Manajemen Bisnis, vol. 2, pp. 25-32. 